International Journal of Environment, Agriculture and Biotechnology
Vol-6, Issue-6; Nov-Dec, 2021
Journal Home Page Available: https://ijeab.com/
Journal DOI: $10.22161 /$ ijeab

\title{
Selected formulations of Bacillus cereus strain SLBE3.1AP with different storage durations for control Fusarium oxysporum f. sp. capsici Chili Plants
}

\author{
Yulmira Yanti ${ }^{1}$, Hasmiandy Hamid ${ }^{1}$, Zulfadhli Syarif ${ }^{2}$, Suci Nur Afeland ${ }^{1}$
}

${ }^{1}$ Department of Plant Pests and Diseases, Agriculture Faculty, Universitas Andalas, Padang, Indonesia

${ }^{2}$ Departmen Agronomy, Agriculture Faculty, University Andalas, Pdang, Indonesia

Received: 03 Oct 2021; Received in revised form: 15 Nov 2021; Accepted: 22 Nov 2021; Available online: 27 Nov 2021

(C)2021 The Author(s). Published by Infogain Publication. This is an open access article under the CC BY license

(https://creativecommons.org/licenses/by/4.0/).

\begin{abstract}
The main disease in chili is fusarium wilt caused by Fusarium oxysporum $f$. sp. capsici that can cause losses up to 100\%. The aim of this study was to obtain a solid formula for the endophytic bacterium Bacillus cereus strain SLBE3.1AP with a carrier that can be stored longer and is effective for controlling Fusarium oxysporum $f$. sp. capsici. This research was an experimental study to see the ability of the solid formula of Bacillus cereus bacteria strain SLBE3.1AP in controlling Fusarium oxysporum $f$. sp. capsici using Completely Randomized Design consisting of 15 treatments and 3 replications. The treatments consisted of carrier material for the formula bagasse, rice straw, bran, fungicide and control. Each solid formula of Bacillus cereus strain SLBE3.1.AP was introduced to chili seeds and seedlings. The results showed that the best formula for controlling Fusarium oxysporum f.sp. capsici and increasing the growth of chili plants was a solid formula of B. cereus strain SLBE3.1AP with 6 weeks storage of bagasse, 4 weeks of storage of rice straw, and 6 weeks of storage of rice bran.
\end{abstract}

Keywords-Bacillus cereus, chili, solid formula, Fusariumoxysporum f. sp. capsici, fusarium wilt.

\section{INTRODUCTION}

Red chili (Capsicum annuum L) is one of the horticultural crop commodities that have high economic value, so it is widely cultivated by farmers (Saptana et al., 2010). The higher demand for chili is sometimes not matched by the results of chili production. Chili productivity in Indonesia was relatively stable from 2014 to 2018, namely 8.35; $8.65 ; 8.47 ; 8.46$; and 8.82 tons/ha (Central Bureau of Statistics, 2019). However, the productivity is stillclassified as low from the potential productivity of chili which can reach 12-15 tons/ha (Hadiyanti, 2016). One of the causes of the low productivity of chili is the attack of plant pathogens (Vivaldy et al., 2017).

One of the main diseases of chili is Fusarium wilt caused by Fusarium oxysporum f. sp. capsici (Yanti et al., 2020), Fusarium wilt disease results in losses and crop failure up to $50 \%$ if not controlled optimally (Rostini, 2011). F. oxysporumf. sp. capsici which is a pathogen of Fusarium wilt disease is a soil borne pathogen that is a soil inhabitant and can survive in extreme conditions with a chlamydiospore survival structure even in the absence of a host. F. oxysporum f. sp. capsici infects plants through wounds on the roots and inhibits the flow of water in the xylem tissue causing the plants to wilt (Chehri et al. 2010).

Efforts to control $F$. oxysporum f. sp. capsici that have been recommended include mechanically removing diseased plants, resistant varieties, crop rotation (Sila and Sopilena, 2016), and synthetic fungicides active ingredient Mancozeb (Sari, 2020) which can have a negative impact on the environment. Based on this, an alternative control is needed, namely: by utilizing microorganisms as biological control agents (Natalia et al., 2014). One of the biological agents that has been tested to control plant diseases and is widely used is endophytic bacteria (Sahu et al., 2019). Endophytic bacteria are bacteria that live in plant tissues and do not cause disease or significant morphological changes in plants (Wang et al., 2019). 
One type of endophytic bacteria that has been widely used as a biological agent is Bacillus spp. because of its ability to sporulate and easily biodegradable by the environment. Biocontrol agents from Bacillus spp. including B. pseudomycoides, B. mycoides, B. thuringiensis, and B. cereus (Yanti et al., 2019). The successful use of Bacillus spp. which can inhibit the growth of the Fusarium oxysporum (Diarta et al., 2016). The use of Bacillus spp. singly causes Bacillus spp. cannot last long and is less than optimal both as a biocontrol agent and as a bioactivator, this is because bacteria need nutrients so that bacterial formulations need to be made (Oktrisna et al., 2017; Yanti et al., 2017).

The aim of the study was to obtain a solid formula of $B$. cereus strain SLBE3.1AP which was effective in controlling Fusarium oxysporumf. sp. capsici on chili plants.

\section{METHODS OF RESEARCH}

The research was carried out on MarchSeptember 2021 at the Microbiology and Phytopathology Laboratory, Department of Plant Diseases Pests and Experimental Gardens, Faculty of Agriculture, Andalas University, Padang. Studyis experimental using Completely Randomized Design (CRD) with 15 treatments and 3 replications. The treatment consisted of formula $B$. cereus strain SLBE3.1AP with various carrier materials from organic waste, namely: bagasse (AT), bran (D) and rice straw (JP) storage $0,2,4$, and 6 weeks with a ratio of 1 $: 1(\mathrm{v} / \mathrm{v})$, fungicide treatment with the active ingredient Mancozeb, treatment without formulation and without inoculation of $F$. oxysporum f. sp. capsici (positive control), treatment without formulation and inoculation with $F$. oxysporum f. sp. capsici (negative control).

\section{Propagation of $B$. cereus strain SLBE3.1AP}

Propagation of B. cereus strain SLBE3.1AP was carried out in liquid culture by means of pure cultures of $B$. cereus strain SLBE3.1AP aged 2x24 hours were taken, put into $25 \mathrm{ml}$ of $\mathrm{NB}$ medium in a culture bottle (volume 50 $\mathrm{ml}$ ) and incubated on a rotary shaker for 24 hours. Next, 1 $\mathrm{ml}$ of preculture results were transferred to $49 \mathrm{ml}$ of sterile coconut water in a culture bottle (100 ml volume) for mainculture and incubated in the same way for $2 \times 24$ hours at $150 \mathrm{rpm}$. Population density was determined by comparing the turbidity of the bacterial suspension with a McFarland scale 8 solution (population density estimated at $10^{8}$ cells/ml) (Klement et al., 1990).

\section{Preparation of solid formula carrier $B$. cereus strain SLBE3.1AP}

The soft part of the bagasse is taken and cut into small pieces and then blended, the tofu pulp is put into aluminum foil and then baked, the rice straw is cut into small pieces then blended and the bran is filtered to get a smooth part. $9.5 \mathrm{~g}$ of each carrier was taken and put into a $100 \mathrm{ml}$ Schott bottle and added $0.5 \mathrm{~g}$ of sucrose, then sterilized using an autoclave at $1 \mathrm{~atm}$ pressure at $121^{\circ} \mathrm{C}$ for 15 minutes. The formula is cooled and $5 \mathrm{ml}$ of suspension is added $B$. cereus strain SLBE3.1AP from mainculture $10^{8}$ cells $/ \mathrm{ml}$. Each formula was stored at room temperature and incubated for 0, 2, 4, and 6 weeks (Yanti et al., 2017).

\section{Pathogenicity Test}

Foc inoculated by injuring the roots of the chili plants with scissors, then the $10 \mathrm{~g}$ Foc rice substrate was immersed into the soil $3 \mathrm{~cm}$ around the roots of the chili plants that had been injured. If the plant shows symptoms of wilting, the inoculum is classified as a pathogen (Chamzurni et al., 2010).

\section{Propagation Foc}

Propagation of Foc using rice media, as much as $2.5 \mathrm{~kg}$ of rice divided by $10 \mathrm{~g}$ for each treatment. The rice is washed and then the rice is dried, then put into a plastic $10 \times 20 \mathrm{~cm}$ and sterilized in an autoclave at a temperature of $1210 \mathrm{C}$ for 30 minutes. After the cold rice, the Foc cultures were cut $1 \times 1 \mathrm{~cm}$ to be inoculated into the rice substrate and incubated for 21 days.

\section{Introduction of formula B. cereus strain SLBE3.1AP}

The introduction of the $B$. cereus formula SLBE3.1AP strain was carried out 2 times, namely at seeding and planting for 15 minutes.

\section{Inoculation Foc}

Before planting, the planting medium was inoculated with Foc $1 \mathrm{~g}$. The Foc rice substrate was transferred to a test tube containing $10 \mathrm{ml}$ of sterile distilled water, then homogenized with a vortex, the suspension was taken with a dropper and the number of conidia was counted using a haemocytometer under a microscope with a magnification of $40 \times 10$. The population used for inoculation into chili plants was $10^{6}$ conidia/ml. Foc was inoculated by immersing $9 \mathrm{~g}$ of Foc rice substrate into the soil to a depth of approximately $3 \mathrm{~cm}$ to maintain soil moisture, the inoculated planting medium was covered with transparent plastic for 3 days, so that $F$. oxysporum $\mathrm{f}$. sp. capsici grows well (Chamzurni et al., 2010).

\section{Observation}

Observations were made on disease development, seedling growth and chili plant growth. The data were analyzed by means of variance, if significantly different 
then continued with Least Significance Differences (LSD) at the $5 \%$ level.

\section{RESULTS AND DISCUSSION}

The introduction of a solid formula of $B$. cereus strain SLBE3.1AP with different storage times in chili plants, the results showed that all introduced formulas were able to suppress the development of Fusarium wilt disease. All formulas of B. cereus strain SLBE3.1AP were stable in suppressing incubation period, disease incidence and severity of Fusarium wilt disease in chili plants. This is presumably due to the type of formula, the nutritional content and the shelf life of the formula, the formula comes from endophytic bacteria which has many enzymes and carriers contain nutrients needed by bacteria to thrive. The best formula has a shelf life of 6 weeks during which time $B$. cereus can produce several resistance compounds. This is in accordance with the opinion of Taghavi et al., (2005) in Yuniawati et al., (2019) endophytic bacteria are able to produce enzymes, salicylic acid, ethylene and secondary metabolite compounds that play a role in inducing plant resistance. According to Hallman et al., (2009) in Munif (2003) before pathogens attack plants, endophytic bacteria that have been associated with plants can act as biological control agents, this is in accordance with the method in this study, namely the introduction of solid formula $B$. cereus strain SLBE3 .1AP before sowing and planting chili seeds, It is hoped that the antagonist bacteria will be able to suppress the growth and development of the fungus $F$. oxysporum which in turn can reduce the attack rate. The results of this study are also in accordance with the research of Yanti et al. (2017), which states that there are5 isolates Indigenous endophytic bacteria are one of them B. cereus strain SLBE3.1AP capable reduce the incidence of Fusarium wilt up to $100 \%$.

The solid formula of B. cereus strain SLBE3.1AP introduced into chili seeds was able to increase chili growth in the seedling phase. The formula was able to increase seedling field emergence, seedling height, number of seedling leaves, wet weight and dry weight of seedlings compared to control (without treatment). From the research results, the stable formula in increasing seedling growth with $100 \%$ effectiveness was the rice straw formula which was stored for 4 weeks and the bagasse formula which was stored for 6 weeks. This is presumably because the best formula is a combination of carriers, which means that the more carriers there are, the more nutrients are contained in the formula, thereby increasing root fertility and plant growth.

Research result This is in accordance with the research of Resti, et al. (2018) which reported that endophytic bacteria can increase seedling growth and emergence of chili seedlings by $95 \%$ compared to controls. According to Lisnawita et al (2016), the increase in plant growth, both plant height and number of leaves, was positively correlated with the contribution of hormones produced by endophytic bacterial isolates. This is in line with the results of research by Marum et al. (2012), who reported that the application of bagasse can increase leaf area, dry weight and fresh weight of plants and provide effective yield growth of radish plants. This is becauseThe organic content of bagasse can reach $50 \%$ and has great potential as a source of organic matter that is useful for soil fertility (Ayu, 2018). Furthermore, Aldi et al. (2016) reported that the PGPR formulation in chilican accelerate the emergence of chili flowers at the age of 54 DAP with an average flower appearance of $84 \%$ of the total experimental plants and increase the number and weight of chilies.

\section{CONCLUSION}

The best formula for controlling Fusarium oxysporum f.sp. capsici and increasing the growth of chili plants was a solid formula of B. cereus strain SLBE3.1AP with 6 weeks storage of bagasse, 4 weeks of storage of rice straw, and 6 weeks of storage of rice bran.

\section{ACKNOWLEDGEMENTS}

The author would like to thank Andalas University which has funded this research in accordance with Decree No. 1868/E4/AK.04/2021 and Agreement/Contract No. 266/E4.1/AK.04.PT/2021.

\section{REFERENCES}

[1] Aldi, SES, Wuryandari, Y., Radiyanto, I. 2016. Growth and Production Response of Chili Plants Due to Administration of Formulas with Active Pseudomonas Fluorescent Isolate 122 in Various Forms and Doses. Journal of Plumula 5(2): $1-13$.

[2] Ayu, DPS 2018. The Effect of Combination of Sugarcane Bagasse and Tea Bagasse as a Planting Media on the Growth of Mustard Pakchoy (Brassica rapa) and Its Contribution to High School Biology Learning. [Thesis] Faculty of Teacher Training and Education, Sriwijaya University.

[3] Central Bureau of Statistics. 2019. Center for Agricultural Data and Information, Ministry of Agriculture of the Republic of Indonesia. Jakarta.

[4] Chamzurni, T., Abduh, MU, Edi, D. 2010. Resistance Test of Several Tomato Varieties Against Wilting Disease. Journal of Agista 14(2): 62-67. 
[5] Chehri, K., Saeed, TJ, Kasa, RNR, Saeed, A., Baharuddin, S. 2010. Occurrence of Fusarium spp. and Fumonisins in Stored Wheat Gains Marketed in Iran. Toxins 2(12): 2816-2.

[6] Diarta, IM, Javandira, C., and Widnyana, IK 2016. Antagonistic Bacteria Pseudomonas spp. and Bacillus spp. Against Fusarium oxysporum Fungus Causes Plant Wilt Disease. Journal of Bakti Saraswati (JBS), 5(1).

[7] Hadiyanti, D. 2016. Variety Improvement Can Increase Red Chili Productivity and Farmers' Income on Dry Land (Case Study in Lubuk Saung Village, Banyuasin III District, Banyuasin Regency). Proceedings of the 2016 National Seminar on Suboptimal Land, Palembang 20-21 October: 649-655.

[8] Hallman, JA., Quadt, HA., Mahafee, WF. and Kloeper, JW. 1997. Bacterial Endophytes in Agricultural Crops. Canadian Journal of Microbiology. 43:895-914.

[9] Klement, Z., Rudolph, K. and Sand, DC 1990. Methods in Phytopathology. Hungary: Kiado Academy.

[10] Lisnawita., Tantawi, AR, Safni, I., Khairunnisa. 2016. Utilization of Agricultural Waste and Local Antagonist Microorganisms to Control Root Chole Nematodes (Meloidogyne spp.) on Potato Plants. North Sumatra University Research Institute.

[11] Marum, J., Zulfita, D., Maulidi. 2012. Effect of Sugarcane Bagasse Compost on Radish Plant Growth and Yield on Red Yellow Podsolic Soil. Agricultural Student Science Journal 2(1): 1- 14.

[12] Munif, A. 2003. The Role of Endophytic Microbes as Biological Agents in Supporting Sustainable Agriculture. National Seminar and Product Title in the Field of Life Sciences. Management and Utilization of Biodiversity in the Framework of Sustainable Development. Bogor.

[13] Natalia, AG, Aeny, TN, and Prasetyo, J. 2014. Effectiveness Test of Trichoderma Spp. with Different Mixed Materials in Inhibiting the Growth of Sclerotium rolfsii Causes Sprout Sprout Disease in Peanuts. Journal of Tropical Agotek, 2(3)

[14] Oktrisna, D., Puspita, F., Zuhry, E. 2017. Bacterial Test of Bacillus sp. formulated with Some Waste against Rice Field Plants (Oryza sativa L.). Let's Faperta. 4(1): 1-12.

[15] Resti, Z., Sulyanti, E., Reflin. 2018. Consortium of Endophytic Bacteria as Biological Control of Rastolnia solanacearum and Stimulator of Chili Plant Growth. Prom Semnas Masy Biodiv Indonesia. 4(2): 208-214.

[16] Rostini, N. 2011. How to Grow Chilies Free of Pests and Diseases. Jakarta: PT Ago Media Pustaka.

[17] Sahu, PK, Singh, S., Gupta, A., Singh, UB, Brahmaprakash, GP, and Saxena, AK 2019. Antagonistic Potential of Bacterial Endophytes and Induction of Systemic Resistance Against Collar Rot Pathogen Sclerotium rolfsii in Tomato. Biological Control, 137, 104014.

[18] Saptana., Daryanto, A., Daryanto, HK, Kuntjoro. 2010. Analysis of Technical Efficiency of Big Red Chili Farming
Production and Farmer Behavior in Facing Risk. Journal of Ago Economics. 28(2): 153-188.

[19] Sari, AL 2020. The Effectiveness of Contact Fungicide with Active Mankozeb in Controlling Potato Leaf Blight (Phytophthora infestans) in Karo Regency on Wet Months and in the Laboratory. [Thesis] University of North Sumatra. Medan.

[20] Schaad NW, Jones JB, And Chun W. 2001. Laboratory Guide for Identification of Plant Pathogenic Bacteria. St Paul: The American Phytopathological Society. 44(4): 546546.

[21] Sila, S., and Sopialena. 2016. The Effectiveness of Several Fungicides on Disease Development and Production $\mathbf{6 5} 6$ B $\mathrm{bi}$ Plants (Capsicum frutescens). Agifor Journal. 15(1): 117130.

[22] Taghavi, S., Barac, T., Geenberg, B., Borremans, B., Vangonsveld, J., and Van Der Lelie, D. 2005. Horizontal Gene Transfer to Endogenous Endophytic Bacteria from Poplar Improves Phytoremediation of Toluene. Applied and environmental microbiology, 71(12), 8500-8505.

[23] Vivaldy, LA, Max, R., Guntur, M. 2017. Incidence of Virus Disease in Chili Plants (Capsicum anuum) in Kakaskasen II Village, North Tomohon District, Tomohon City. Journal of In cocos. 1(6): 1-9.

[24] Wang, SS, Liu, JM, Sun, J., Sun, YF, Liu, JN, Jia, N., and Dai, XF 2019. Diversity of Culture-Independent Bacteria and Antimicrobial Activity of Culturable Endophytic Bacteria Isolated from Different Dendro bium stems. Scientific reports, 9(1), 1-12.

[25] Yanti, Y., Habazar, T., Resti, Z. 2017a. Solid Formulation of Rhizobacteria Indigenous Bacillus thuringiensis Ts2 and Storage Time to Control Pustule Disease of Xhantomonas axonopodis vp. Glycine. Journal of Tropical Plant Pests and Diseases. 17(1):9-18.

[26] Yanti, Y., Warnita., Reflin., Busniah, M. 2017b. Identificatiion and Characterizations of Potential Indigenos Endophytic Bacteria which Had Ability to Promote Gowth Rate of Tomato and Biocontrol Agents of Ralstonia solanacearum and Fusarium oxysporum f. sp. solani. Indonesian Microbiology. 11(4): 117-122.

[27] Yanti, Y., Hamid, H., and Habazar, T. 2020. The Ability of Indigenous Bacillus spp. Consortia to Control the Anthracnose Disease (Colletrotricum capsici) and Increase the Gowth of Chili Plants. Biodiversity. 21(1): 179-186.

[28] Yuniawati, R., Fatimah, S., Indrayati. R., Manzila, I., Priyatno, T., Susilowati, D. 2019. Improving Growth and Quality of Big Red Chili Fruit with Growth Hormone from Endophytic Bacteria. Journal of Ago Biogen 15(2): 75-82. 
FIGURES AND TABLES

Table 1. The development of Fusarium wilt disease in chili plants introduced by each treatment

\begin{tabular}{l|r|l|r|r|r|r|r|r}
\hline \multicolumn{2}{c|}{ Treatment } & \multicolumn{7}{c}{ Disease Progress } \\
\hline $\begin{array}{c}\text { Carrier } \\
\text { Material }\end{array}$ & $\begin{array}{c}\text { Storage } \\
\text { Time }\end{array}$ & $\begin{array}{c}\text { Incubation } \\
\text { Period }\end{array}$ & $\begin{array}{c}\text { Effectivene } \\
\text { ss } \%)\end{array}$ & $\begin{array}{c}\text { Disease } \\
\text { Incidence } \\
(\%)\end{array}$ & $\begin{array}{c}\text { Effectiv } \\
\text { eness } \\
(\%)\end{array}$ & $\begin{array}{c}\text { Disease } \\
\text { Severity }(\%)\end{array}$ & $\begin{array}{c}\text { Effectivene } \\
\text { ss }(\%)\end{array}$ & $\begin{array}{r}\text { Attack } \\
\text { Criteria }\end{array}$ \\
\hline Bagasse & 0 & $21.00 \mathrm{cde}$ & 117.16 & $100.00 \mathrm{a}$ & 0.00 & $41.67 \mathrm{ab}$ & 16.53 & Heavy \\
Bagasse & 2 & $29.67 \mathrm{abc}$ & 206.82 & $33.33 \mathrm{ab}$ & 66.67 & $16.00 \mathrm{bc}$ & 63.90 & Light \\
Bagasse & 4 & $30.67 \mathrm{ab}$ & 217.16 & $33.33 \mathrm{ab}$ & 66.67 & $14.00 \mathrm{bc}$ & 68.41 & Light \\
Bagasse & 6 & $34.00 \mathrm{a} *$ & 251.60 & $0.00 \mathrm{~b} *$ & 100.00 & $0.00 \mathrm{c} *$ & 100.00 & Healthy \\
Rice straw & 0 & $19.00 \mathrm{de}$ & 96.48 & $100.00 \mathrm{a}$ & 0.00 & $37.67 \mathrm{ab}$ & 15.02 & Heavy \\
Rice straw & 2 & $27.33 \mathrm{abcd}$ & 182.62 & $66.67 \mathrm{ab}$ & 33.33 & $24.67 \mathrm{abc}$ & 44.34 & Currently \\
Rice straw & 4 & $29.67 \mathrm{abc}$ & 206.82 & $33.33 \mathrm{ab}$ & 66.67 & $15.00 \mathrm{bc}$ & 66.16 & Light \\
Rice straw & 6 & $30.67 \mathrm{ab}$ & 217.16 & $33.33 \mathrm{ab}$ & 66.67 & $16.33 \mathrm{bc}$ & 63.16 & Light \\
Bran & 0 & $18.33 \mathrm{ef}$ & 89.55 & $100.00 \mathrm{a}$ & 0.00 & $39.33 \mathrm{ab}$ & 15.02 & Heavy \\
Bran & 2 & $30.67 \mathrm{ab}$ & 217.16 & $33.33 \mathrm{ab}$ & 66.67 & $16.33 \mathrm{bc}$ & 63.16 & Light \\
Bran & 4 & $30.67 \mathrm{ab}$ & 217.16 & $33.33 \mathrm{ab}$ & 66.67 & $15.67 \mathrm{bc}$ & 64.65 & Light \\
Bran & 6 & $30.67 \mathrm{ab}$ & 217.16 & $33.33 \mathrm{ab}$ & 66.67 & $11.67 \mathrm{bc}$ & 73.67 & Light \\
Mancozeb & - & $24.33 \mathrm{bcde}$ & 151.60 & $66.67 \mathrm{ab}$ & 33.33 & $30.33 \mathrm{abc}$ & 42.09 & Currently \\
+ control & - & $34.00 \mathrm{a} *$ & 251.60 & $0.00 \mathrm{~b} *$ & 100.00 & $0.00 \mathrm{c} *$ & 100.00 & Healthy \\
Control - & - & $9,667 \mathrm{f}$ & 0.00 & $100.00 \mathrm{a}$ & 0.00 & $54.00 \mathrm{a}$ & 0.00 & Very \\
& & & & & & & & heavy
\end{tabular}

*plants did not show symptoms until the end of observation (34 DAI)

*Numbers followed by the same lowercase letter in the same column are not significantly different according to LSD at the $5 \%$ level.

Table 2. Growth of chili seedlings introduced for each treatment

\begin{tabular}{|c|c|c|c|c|c|c|c|c|c|c|c|c|}
\hline \multicolumn{2}{|c|}{ Treatment } & \multicolumn{11}{|c|}{ Seed growth } \\
\hline $\begin{array}{c}\text { Carrier } \\
\text { Material }\end{array}$ & $\begin{array}{l}\text { Storag } \\
\text { e Time }\end{array}$ & $\begin{array}{c}\text { Power } \\
\text { appears } \\
\text { field }\end{array}$ & $\begin{array}{l}\text { Effect } \\
\text { ivene } \\
\text { ss (\%) }\end{array}$ & $\begin{array}{c}\text { Seedlin } \\
\mathrm{g} \text { height } \\
(\mathrm{cm})\end{array}$ & $\begin{array}{c}\text { Effect } \\
\text { ivene } \\
\text { ss } \\
(\%)\end{array}$ & $\begin{array}{c}\text { Number } \\
\text { of } \\
\text { leaves } \\
\text { (strands } \\
\text { ) }\end{array}$ & $\begin{array}{l}\text { Effect } \\
\text { ivene } \\
\text { ss }(\%)\end{array}$ & $\begin{array}{c}\text { Effecti } \\
\text { veness } \\
(\%)\end{array}$ & $\begin{array}{c}\text { Wet } \\
\text { weight } \\
\text { (gam) }\end{array}$ & $\begin{array}{c}\text { Effecti } \\
\text { veness } \\
(\%)\end{array}$ & $\begin{array}{c}\text { Dry } \\
\text { weight } \\
\text { (gam) }\end{array}$ & $\begin{array}{l}\text { Effectivenes } \\
\mathrm{s}(\%)\end{array}$ \\
\hline Bagasse & 0 & 96.00 & 27.78 & $11.00 \mathrm{ij}$ & 26.87 & $\begin{array}{l}5.66 \\
\text { bcde }\end{array}$ & 62.00 & 26.08 & $0.12 \mathrm{jkl}$ & 33.33 & 0.02 ghij & 00.00 \\
\hline Bagasse & 2 & 96.00 & 27.78 & $\begin{array}{l}11.50 \\
\mathrm{gh}\end{array}$ & 32.64 & $5.33 \mathrm{de}$ & 52.28 & 78.26 & $0.23 \mathrm{~cd}$ & 155.55 & $0.05 \mathrm{bcde}$ & 150.00 \\
\hline Bagasse & 4 & 96.00 & 27.78 & $10.33 \mathrm{k}$ & 23.06 & $5.99 \mathrm{ef}$ & 42.85 & 78.26 & $\begin{array}{l}0.14 \\
\text { ghijk }\end{array}$ & 55.55 & 0.04 efgh & 100.00 \\
\hline Bagasse & 6 & 100.00 & 33.33 & $\begin{array}{l}12.33 \\
\mathrm{de}\end{array}$ & 42.21 & $6.33 \mathrm{ab}$ & 80.85 & 147.82 & $0.26 \mathrm{bc}$ & 188.88 & $0.06 \mathrm{abc}$ & 200.00 \\
\hline Rice straw & 0 & 96.00 & 27.78 & $\begin{array}{l}11.67 \\
\text { fg }\end{array}$ & 34.60 & $5.33 \mathrm{de}$ & 52.28 & 43.47 & $0.12 \mathrm{cl}$ & 33.33 & 0.03 fghi & 50.00 \\
\hline Rice straw & 2 & 96.00 & 27.78 & $11.00 \mathrm{ij}$ & 26.87 & 6.00 & 71.42 & 113.04 & $0.19 \mathrm{def}$ & 111.11 & $0.04 \mathrm{def}$ & 100.00 \\
\hline
\end{tabular}




\begin{tabular}{|c|c|c|c|c|c|c|c|c|c|c|c|c|}
\hline & & & & & & bcd & & & & & & \\
\hline Rice straw & 4 & 100.00 & 33.33 & $\begin{array}{l}12.83 \\
\mathrm{bc}\end{array}$ & 47.98 & $\begin{array}{l}5.66 \\
\text { bcde }\end{array}$ & 62.00 & 113.04 & $0.22 \mathrm{~cd}$ & 144.44 & 0.05 cde & 150.00 \\
\hline Rice straw & 6 & 100.00 & 33.33 & $12.00 \mathrm{ef}$ & 38.40 & $\begin{array}{l}5.66 \\
\text { bcde }\end{array}$ & 62.00 & 104.34 & $\begin{array}{l}0.15 \\
\text { ghijk }\end{array}$ & 66.67 & 0.05 cde & 150.00 \\
\hline Bran & 0 & 92.00 & 22.22 & $\begin{array}{l}11.33 \\
\text { ghi }\end{array}$ & 30.68 & $5.33 \mathrm{de}$ & 52.28 & 39.13 & 0.081 & -4.44 & $0.01 \mathrm{j}$ & -50.00 \\
\hline Bran & 2 & 100.00 & 33.33 & $\begin{array}{l}12.33 \\
\mathrm{de}\end{array}$ & 42.21 & $5.33 \mathrm{de}$ & 52.28 & 69.56 & $\begin{array}{l}0.15 \\
\text { ghijk }\end{array}$ & 66.67 & 0.02 ghij & 00.00 \\
\hline Bran & 4 & 96.00 & 27.78 & $10.66 \mathrm{jk}$ & 19.14 & $\begin{array}{l}5.66 \\
\text { bcde }\end{array}$ & 62.00 & 95.65 & 0.13 hijk & 44.44 & $0.07 \mathrm{ab}$ & 250.00 \\
\hline Bran & 6 & 96.00 & 27.78 & $\begin{array}{l}12.50 \\
\mathrm{~cd}\end{array}$ & 44.17 & $\begin{array}{l}6.00 \\
\text { bcd }\end{array}$ & 71.42 & 56.52 & $0.20 \mathrm{de}$ & 122.22 & 0.04 efgh & 100.00 \\
\hline Mancozeb & - & 92.00 & 22.22 & $11.16 \mathrm{hi}$ & 28.83 & $5.16 \mathrm{ef}$ & 47.71 & 21.73 & $0.17 \mathrm{efgh}$ & 88.89 & $0.02 \mathrm{hij}$ & 00.00 \\
\hline Control & - & 75.00 & 00.00 & 8.671 & 00.00 & $3.50 \mathrm{~g}$ & 00.00 & 00.00 & 0.091 & 00.00 & $0.02 \mathrm{ij}$ & 00.00 \\
\hline
\end{tabular}

*Numbers followed by the same lowercase letter in the same column are not significantly different according to LSD at the $5 \%$ level. 